internal trading within a country or for the carrying out of seed health surveys. That seed health surveys may yield results which are both of interest and importance has already been shown by that made for the health of flax seed produced in the United Kingdom. Although other techniques may be found to be more convenient in some instances, as, for example, in the case of blind seed disease of ryegrass caused by Phialea temulenta Prill. and Delacr.9, yet the Ulster Method and the Modified Ulster Method would appear to have a wide application and are likely to prove of considerable value where the measurement of seed health is achieved by the direct examination of the seed for the presence of fungal pathogens.

${ }^{1}$ Muskett, A. E., and Malone, Y. P., Ann. App. Biol., 28, 8 (1941). 2 Muskett, A. E. and Colhoun, J., "Diseases of the Flax Plant" (W. and G. Baird, Belfast, 1947 ).

${ }^{3}$ Muskett, A. E., Ann. Bot., N.S., 1, 763 (1937).

${ }^{1}$ Muskett, A: E., Ann. Bot., N.S., 2, 699 (1938).

'Wilson, J. K., Amer. J. Bot., 2, 420 (1915).

"Noble, M., Nature, 168, 534 (1951).

' Groves, J. W., and Skolko, A. J., Canad. J. Res., 22, 190 (1944)

'Muskett, A. E., Trans. Brit. Mycol. Soc., 33, 1 (1950).

'Muskett, A. E., Trans. Brit. Mycol. Soc., 30, 74 (1948).

\section{DOCUMENTATION OF SCIENCE}

$\mathbf{N}$ place of the usual annual report, the Inter1 national Council of Scientific Unions has this year arranged for its Abstracting Board to issue a paper by its secretary, Prof. G. A. Boutry, which was read at the International Congress on Documentation of Applied Chemistry, held in London during November 23-25. The paper describes this venture in international co-operation from its origin at an international conference on scientific abstracting which was held in Paris in June 1949, organized by the Department of Exact and Natural Sciences of the United Nations Educational, Scientific and Cultural Organization. Twenty-four countries were represented, and eight of the eleven scientific unions federated with the International Council of Scientific Unions. One of the recommendations in the Final Act emphasized the importance of establishing good co-operation between existing scientific abstracting services; another urged that all original articles appearing in scientific periodicals should include an author's abstract prepared according to an agreed set of rules; and a third recommendation proposed the establishment of a single International Journal of Physics Abstracts, preferably bilingual. As a result of these three recommendations, a joint commission was formed by the Council to discuss further this problem of co-operation in physics abstracting. The Commission first met in Paris on December 20, 1949, and it was at once realized that any practical measures involved the co-operation of those concerned with producing Science Abstracts and the Bulletin Analy. tique du Centre National de la Recherche Scientifique. A meeting between representatives of the joint commission and of these two abstracting journals was arranged in London in September 1950.

At this meoting it was agreed to urge all leading periodicals publishing original papers in physics to undertake to publish authors' summaries prepared according to rules set forth by the Royal Society and by the Unesco conference of 1949 , and that these summaries, irrespective of the language in which the original papers were written, should be printed either in English or French. It was also agreed that some responsible international organization should ask the

publishers of periodicals, whenever advisable, for special rates of subscriptions and, in addition, to ask the editors of important periodicals to send corrected page-proofs of their issues, or at least clippings of the synopses, to the offices of Science Abstracts and of the Bulletin Analytique at the time of going to press. Finally, the editors of these two abstracting periodicals agreed to co-operate and remain in close contact, and to speed up and increase the efficiency of their work, by whatever means they thought best; it was also agreed that some responsible permanent international organization should be able to help them if they needed such assistance. Accordingly, when the joint commission considered these proposals at its next meeting in July 1951, it decided to ask the International Council of Scientific Unions to dissolve the joint commission and constitute a Board for the International Abstracting Service, on which would be represented, besides the Council itself, the abstracting journals admitted as members (initially Science Abstracts and the Bulletin Analytique).

This suggestion was studied by Unesco and the International Council of Scientific Unions, and on May 16, 1952, it was agreed to establish such an Abstracting Board, maintained by funds originating from Uneseo and the International Council and with the general secretary of the latter body as a permanent member. The Board formally began to operate on June I, 1952, and its first general assembly met at Strasbourg in July 1953, when rules and by-laws were adopted and an executive committee appointed, the composition of which for 1953-56 is : President, Dr. P. Bourgeois ; Secretary, Prof. G. A. Boutry ; Members, Dr. E. Hutchisson, Prof. A. V. Hill and Prof. J. Wyart.

As a result of the Board's work, with the exception of a few publications printed in the United Kingdom, all periodicals containing original articles on physics and published in Australia, Belgium, Canada, France, Italy, the Netherlands, the United Kingdom and the United States have agreed to publish authors' summaries in English or French or both, written according to approved rules. Moreover, editorial co-operation has been so thorough that usually the member. journals print these summaries verbatim. Attempts to obtain the same co-operation in Scandinavian countries and in Germany continue, and the four main Japanese journals of physics have also been approached.

Fifty-five periodicals printed in the United Kingdom, the United States, the Netherlands, France, Germany, Italy, Sweden, Japan and the U.S.S.R. send to the Board or its associates, generally by air-mail, complete page-proofs, or, in a few cases, clippings of authors' summaries. In 1954 the Board arranged with the director of the Institute of Documentation of the U.S.S.R. Academy of Sciences to exchange proofs of six Russian and eight American periodicals for purposes of documentation, and this exchange started in February 1955. The proofs of the Russian periodicals are microfilmed in Paris and forwarded to the editors of the member-journals. The periodicals exchanged are as follows:

U.S.S.R.

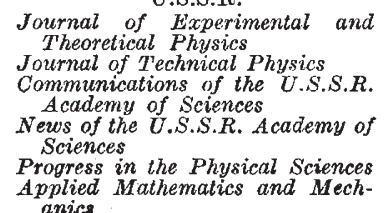
Theor of Experimental and ournal of Technical Physic Communications of the U.S.S.R. Academy of Sciences Sciences Progress in the Physical Sciences anics
UNITED STATES American Journal of Physics Journal of the Acoustical Society Journal of the Journal of Applied Physics Physical Review Journal of the Optical Society of America Review of Scientific Instruments Roviews of Modern Physics 
The Board has also conducted an inquiry in twelve European countries as to the feasibility of a comprehensive Russian-to-English translating service in physics, and as an outcome of this inquiry the American Institute of Physics has announced the initiation, in November 1955, of a complete English translation of the Russian Journal of Theoretical and Experimental Physics.

Together with the Publication Committee of the International Union of Pure and Applied Physies, the Board has also promoted the publication of articles reviewing the work of the principal schools of research in physics in the U.S.S.R. and other Slavonic countries, and it is co-operating with the same body in the revision of the Universal Decimal Classification in physics. Stops have also been taken to facilitate the abstracting of non-periodical publications in physics.

As early as 1950 the Executive Committee of the International Council of Scientific Unions had expressed the opinion that the joint commission should be concerned with the abstrasting of both chemical and physical literature, and this view was endorsed by the Council in October 1951, though later a proviso was added that work on chemical documentation should not be attempted before sufficient progress had been made in the field of physics. It was only in 1954, accordingly, that the Abstracting Board was ready to extend its activities into chemical literature, and this extension was authorized by the Council in October of that year. When notified of this decision, the International Union of Pure and Applied Chemistry, now represented on the Board by Dr. L. H. Lampitt, recommended Chemical Abstracts and the Bulletin Analytique as member-journals for chemical abstract ing in English and French, respectively. These journals were unanimously elected to the Board and remain the only member-journals for chemistry. The editors of a number of important chemical periodicals have already been approached with the view of organizing the exchange of page-proofs. The International Union of Mechanics and the International Union of Biology have also expressed interest in the work of the Board, and Prof. Boutry concludes his paper with a warning that the time may be due when full-time salaried officials will be required for the work of the Board in place of honorary officials.

\section{CONNECTIVE TISSUE AND ITS CHANGES WITH AGE}

$\mathrm{T}$ HE British Society for Research on Ageing held a meeting in the Littlewood Hall of the General Infirmary, Leeds, on January 20, under the chairmanship of Prof. R. E. Tunbridge, at which four papers were read and discussed. The first, by Dr. M. K. Keech, Dr. R. Reed and Miss M. J. Wood, dealt with the characterization of elastic tissue by means of the electron microscope. They presented evidence that the variable morphology shown by normal elastic tissue fibres from various sites indicates that elastin, the fibrous protein entity assumed to be present in all forms of elastic tissue, is a complex system, consisting of fibres coated with a dense, amorphous material. They also produced evidence that dermal collagen fibrils, either fresh or prepared substantially free from ground substance, when treated at $37^{\circ} \mathrm{C}$. with alkaline buffer solutions of $p H \mathrm{H} \cdot 8$, or with periodate solution, $p \mathrm{H} 5 \cdot 0$, transform into structures closely resembling those in naturally occurring elastic tissue (see Nature, 176, 966 ; 1955 ; and $J$. Gerontol., $10,388 ; 1955)$. These structures stain like elastica and also are attacked by the enzyme elastase.

The so-called dense, moth-caten fibres ( $A n n$. Rheumat. Dis., 14, 19 ; 1955), which result from the action of bacterial collagenase on collagen fibrils, also transform, when hoated in water, to similar elastin-like structures (J. Path. and Bact., in the press). The importance of these findings lies in the fact that the moth-eaten fibres are an index to the age of tho collagen from which they arise. In the age range $0-20$ years, collagen, when treated with collagenase, forms many such fibres. From collagen of ages 20-50 years, however, their number gradually decreases, while above the age of 50 none is produced. It is concluded, therefore, that the products of collagen breakdown become coated with a dense amorphous material to form the elastin-like structures. Apparently the coating material is present in young collagen, but gradually decreases in amount with age. Elastic fibres from ox ligamentum nuchæ, when treated with boiling 1 per cent acetic acid solution for $1 \mathrm{hr}$, are apparently devoid of collagen fibrils as judged by the electron microscope. Collagenase action, however, reveals that they still contain many short fibrils of degenerate collagen. In general, therefore, there are strong morphological grounds for believing that material resembling elastic tissue can originate from the breakdown of collagen.

In the second paper, Dr. P. F. Lloyd discussed some problems relating to the polysaccharide components of connective tissue, and dealt with these under three headings : the type of polysaccharide(s) present; the nature of the linkages binding polysaccharides to other components; and the function of the polysaccharides or polysaccharide-containing complexes. Knowledge of the first two is essential for a full understanding of the third, and all three need to be studied before the wider problems concerning the nature of the changes which occur in connective tissue on ageing can be seen in true perspective.

To facilitate work on connective tissue in general, and on elastic tissue in particular, paper ionophoretic and infra-red analytical methods have been developed. Paper ionophoresis on an apparatus fitted with 'Perspex' condensers above and below the paper appears to give excellent separations of mucopolysaccharides (potential gradient $18 \mathrm{~V} . / \mathrm{cm}$.). It has been found that chondroitin sulphuric acid-A moves at a faster rate than chondroitin sulphuric acids-C and -B. The mobility of the latter polysaccharide is increased after treatment with testicular hyaluronidase. Extraction of ligamentum nuchæ with 5 per cent saline followed by fractionation leads to the isolation of chondroitin sulphuric acid-B and $a$ hyaluronic acid, the nature of which has been demonstrated by chemical and physical methods. In addition, this elastic tissue contains probably chondroitin and also a now type of connective tissue polysaccharide which is either a sulphated hyaluronic acid or a sulphated polysaccharide containing both glucosamine and chondrosamine in approximately equal amounts.

Extraction with 10 per cent calcium chloride has led to the separation of an insoluble mucoprotein containing about 8 per cent polysaccharide. In its behaviour on treatment with elastase, it rosembles elastin ( 0.5 per cent polysaccharide) ; and Dr. Lloyd expressed the opinion that it would serve as a con- 